Proceedings

\title{
Development and evaluation of IPM modules against fruit borer, Helicoverpa armigera (Hub.) (Lepidoptera: Noctuidae) infesting tomato crop in semi arid region ${ }^{+}$
}

\author{
Pawan Kumar Choudhary 1, S R Dhaka 2, Mukesh Nitharwal 2,* and Bhanwar Lal Jakhar ${ }^{1}$ \\ 1 Division of Entomology, RARI, Durgapura, Jaipur, Rajasthan, India; pkchoudhary@gmail.com (P.K.C.), \\ bljakhar.ento@sknau.ac.in (B.L.J.) \\ 2 College of Agriculture, Fatehpur, Sikar, Rajasthan, India; srdhaka.ento.rari@sknau.ac.in (S.R.D.) \\ * Correspondence: mukeshnitharwal.ento@sknau.ac.in ; Tel.: +91-7597434146 \\ + Presented at the 1st International Electronic Conference on Entomology (IECE 2021), 1-15 July 2021; \\ Available online: https://iece.sciforum.net/.
}

Citation: Choudhary, P. C.; Dhaka, S.R.; Pereira, R. C. Nitharwal, M.; Jakhar, B.L. Development and evaluation of IPM modules against fruit borer, Helicoverpa armigera (Hub.) (Lepidoptera: Noctuidae) infesting tomato crop in semi arid region, in Proceedings of the 1st International Electronic Conference on Entomology, 1-15 July 2021, MDPI: Basel, Switzerland, doi:10.3390/IECE-10640

Published: 07 July 2021

Publisher's Note: MDPI stays neutral with regard to jurisdictional claims in published maps and institutional affiliations.

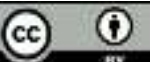

Copyright: () 2021 by the authors. Submitted for possible open access publication under the terms and conditions of the Creative Commons Attribution (CC BY) license (http://creativecommons.org/licenses /by/4.0/).

\begin{abstract}
IPM modules evaluated in present study were showed significantly judicious over untreated control. Among them, the efficacy of module 7 comprising Emamectin benzoate 5\% SG @ 200 ml/ha + chlorantraniliprole 18.5 EC @ 150 ml/ha + Novaluron 10 EC @ 1 L/ha was found best in controlling the H. armigera (0.43 larvae/plant with 8.46 and $7.63 \%$ of fruit damage both on number and weight basis, respectively) in tomato. While, the lowest efficacy was recorded in module 2 comprising Trichogramma sp. (@150,000/ha + HaNPV@ 300 LE/ha + NSKE@ 10\% (1.28 larvae/plant and 23.05 and 21.62 \% of fruit damage both on number and weight basis, respectively). Module 7 recorded maximum fruit yield of $269.73 \mathrm{q} /$ ha with highest efficacy, whereas, it was lowest in module $8(173.47 \mathrm{q} / \mathrm{ha})$ kept as untreated control. Module 7 reported the maximum increase in yield over control (96.32 q/ha).
\end{abstract}

Keywords: Fruit borer; Helicoverpa armigera; IPM; Module; semi-arid; tomato

\section{Introduction}

Tomato (Lycopersicon esculentum Mill.), as solanaceous vegetable used both as fresh and processing industry in India and it ranks second in importance next to potato. Lycopene (60$90 \mathrm{mg} / \mathrm{kg}$ ) is one the important and rich source of vitamins that makes it an important dietary constituent of human beings [1]. Nutritional contribution with high biological activity in human diet ranked it first among all vegetables $[2,3]$. In Rajasthan, India tomato crop occupied 18.12 lakh hectare area with production of 88.73 lakh tonnes and productivity is 4.8 tonnes/ha [4]. Tomato's tenderness and softness are like other important vegetable which make it more prone to insect pests and diseases. It ruined by an array of pests like sucking pest's i.e. jassids, Amrasca biguttula (Ishida), thrips, Thrips tabaci (Linn.), aphid, Aphis gossypii (Glover), Lipaphis erysimi (Kalt.), Myzus persicae (Sulzer) and whitefly, Bemisisa tabaci (Genn.) however, the important one to cause damage is by fruit borers [5]. Fruit borers' viz., Helicoverpa armigera (Hubner) and Spodoptera litura Fabricius hampered the yield potential of crop, with a resultant yield loss ranging from 20 to 60 per cent as combined, on developing fruits $[6,7,8]$.

H. armigera is voracious feeder in habit, having high mobility, and fecundity with multivoltine and overlapping generations makes it as pest of high magnitude that cause direct attack on fruiting structures. Losses due to this pest in crops i.e. cotton, pigeon pea, ground- 
nut, sorghum, pear millet and other crops of economic importance reported up to Rs 100 billion [9], therefore assessment of losses in tomato crop was undertake in this study. In the Semi arid eastern plain zone and in Jaipur district of Rajasthan, the large proportion of tomatoes produced by small and marginal farmers. Among the farmers of this region interest of taking tomato production than any other vegetables is high due to the possibility of multiple harvests, resulting in high economic return per unit area

A successful pest management emphasized on knowledge of bionomics and population dynamics of target pest species to maintain damage below the economic threshold while reducing the risk of pesticide poisoning [10]. IPM practices have historically been focused on insects comprises numerous economically important pests above economic threshold level, and on controlling them with less harmful impact in agricultural environments [11,12]. The use alternatives and novel methods for pest control or biorational control are the challenges of pest control for the twenty-first century and research emphasis on to reduce the use of synthetic pesticides, mainly broad-spectrum insecticides in plant protection. These chemicals are harmful through either as pesticide residual effects, pollution, resistance, or through direct effects on human and beneficial organisms. Now scenario changes towards the sustainable agriculture with more selective and safer insecticides specifically harmful to pests without any adverse effect to beneficial insects and other non-target organisms. Hence, an experiment was laid out to evaluate different IPM modules for management of tomato fruit borer and to popularize this developed module among the farmers' of the state to increase their income through newly developed modules.

\section{Materials and Methods}

Studies were conducted for development and evaluation of IPM modules against tomato fruit borer was conducted during spring season 2017 and 2018. The experimental field situated at Rajasthan Agricultural Research Institute, Durgapura, Jaipur (26 51' 25.344" N, 75 $47^{\prime}$ 24.936 " E). The plot size was kept $3.6 \times 2 \mathrm{~m}^{2}$ keeping row to row and plant to plant distances of $60 \mathrm{~cm}$ and $40 \mathrm{~cm}$, respectively. The seeds of tomato variety RS-2 recommended for this region were prepared in nursery bed in second week of January and thirty day old seedling were transplanted in the second week of February during both the years. A complete simple randomized block design (RBD) with eight treatments (IPM modules) (Table 1) including untreated control each replicated thrice. Observations on number of larvae per plant were recorded a day before and five days after each treatment (DAT) from five randomly selected and tagged plants in each treatment plot. Total number of fruits and damaged fruits harvested at each picking from each plot was also counted and weighed and were converted to per cent basis. Per cent fruit damage on number and weight basis was worked out by recording number of damaged fruits and total number of fruits from five tagged plants in each plot at each picking and calculated by using following formulae:

$$
\begin{aligned}
& \% \text { Fruit Infestation (Number basis) }=\frac{\text { Number of infested or damaged fruits }}{\text { Total number of Fruits }} \times 100 \\
& \% \text { Fruit Infestation (Weight basis) }=\frac{\text { Number of infested or damaged fruits }}{\text { Total number of Fruits }} \times 100
\end{aligned}
$$

The weight of sound fruits of each picking were recorded individually for each treatment plot and the yield was calculated by adding the yield from all pickings for each plot. The yield was then converted into per hectare basis with the following formula.

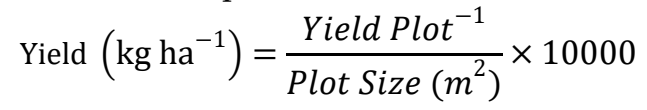


Table 1. Details of the IPM Modules

\begin{tabular}{|c|c|c|c|}
\hline $\begin{array}{c}\text { S. No. } \\
\text { Modules }\end{array}$ & I Release/Application (DAS) & $\begin{array}{l}\text { II Application } \\
\text { (DAS) }\end{array}$ & III Application (DAS) \\
\hline M1. & NSKE @10\% & HaNPV@300 LE/ha & Bt.k (dipel SL) @1.5 L/ha \\
\hline M2. & Trichogramma sp.@150,000/ha & HaNPV@300LE/ha & NSKE @10\% \\
\hline M3. & NSKE @10\% & HaNPV@300 LE/ha & Indoxacarb 14.5 SC @500ml/ha \\
\hline M4. & HaNPV@300LE/ha & Bt.k (dipel SL) @ 1.5 L/ha & Acephate75\%SP @ 2 kg/ha \\
\hline M5. & Bt.k (dipel SL) @1.5 L/ha & Spinosad 45 SC @ 200ml/ha & $\begin{array}{c}\text { Flubendiamide } 48 \% \text { SC @ } 200 \\
\mathrm{ml} / \mathrm{ha}\end{array}$ \\
\hline M6. & $\begin{array}{c}\text { Trap crop (1 row marigold):15 rows } \\
\text { tomato }\end{array}$ & NSKE @10\% & HaNPV@300LE/ha \\
\hline M7. & $\begin{array}{c}\text { Emamectin benzoate 5\% SG @200 } \\
\mathrm{ml} / \mathrm{ha}\end{array}$ & $\begin{array}{c}\text { Chlorantraniliprole } 18.5 \text { EC @150 } \\
\mathrm{ml} / \mathrm{ha}\end{array}$ & Novaluron 10 EC \\
\hline M8. & Untreated control & & \\
\hline
\end{tabular}

\section{Results}

\subsection{Larvae Population}

Results indicated that all the treatment schedules in different modules significantly superior over untreated control (1.93 larvae/plant). Module 7 comprising Emamectin benzoate 5\% SG@ 200 ml/ha + Chlorantraniliprole 18.5 EC @ 150 ml/ha + Novaluron 10 EC @ 1 L/ha was found best in controlling the $H$. armigera $(0.43$ larvae/plant) in tomato followed by module 5 comprising Bt.k (dipel SL) @ 1.5 L/ha + Spinosad 45 SC @ 200ml/ha + Flubendiamide 48\% SC @ $200 \mathrm{ml} / \mathrm{ha}$ (0.59 larvae/plant). Module 3 comprising NSKE @ 10\% + HaNPV@ 300 LE/ha + Indoxacarb 14.5 SC @ 500ml/ha and 4 comprising HaNPV@ 300 LE/ha + Bt.k (dipel SL) @ 1.5 L/ha + Acephate75\%SP @ 2 kg/ha constituted the next group of effective treatments where 0.83 and 0.97 larvae/plant were recorded. With moderate efficacy, module 1 comprising NSKE $@ 10 \%+H a N P V @ 300$ LE/ha + Bt.k (dipel SL) @ 1.5 L/ha (1.16 larvae/plant) and module 6 comprising Trap crop (1 row marigold):15 rows tomato + NSKE @10\% + HaNPV@ 300 LE/ha (1.20 larvae/plant) were at par to each other. Among the IPM modules, lowest efficacy was recorded in module 2 comprising Trichogramma sp. (@ 150,000/ha + HaNPV@ 300 LE/ha + NSKE @10\% (1.28 larvae/plant) (Table 2). 
Table 2: Effectiveness of different modules on fruit damage (Weight and Number basis) caused by H. armigera larvae and mean larval population recorded in tomato during 2017 and 2018 (Pooled)

\begin{tabular}{|c|c|c|c|c|c|c|c|c|c|c|}
\hline & \multirow[t]{2}{*}{ Modules } & \multicolumn{3}{|c|}{$\begin{array}{l}\text { Mean per cent fruit damage } \\
\text { (Weight basis)* }\end{array}$} & \multicolumn{3}{|c|}{$\begin{array}{l}\text { Mean per cent fruit damage } \\
\text { (Number basis)* }\end{array}$} & \multicolumn{3}{|c|}{$\begin{array}{l}\text { Mean larval population of } H \text {. } \\
\text { armigera/plant** }\end{array}$} \\
\hline & & 2017 & 2018 & Pooled & 2017 & 2018 & Pooled & 2017 & 2018 & Pooled \\
\hline M1. & $\begin{array}{c}\text { NSKE@10\%+HaNPV@300 LE/ha + Bt.k (dipel SL) } \\
@ 1.5 \text { L/ha }\end{array}$ & $\begin{array}{c}19.53 \\
(26.21)\end{array}$ & $\begin{array}{c}21.18 \\
(27.39)\end{array}$ & $\begin{array}{c}20.36 \\
(26.80)\end{array}$ & $\begin{array}{c}20.68 \\
(27.04)\end{array}$ & $\begin{array}{c}22.56 \\
(28.34)\end{array}$ & $\begin{array}{c}21.62 \\
(27.69)\end{array}$ & $\begin{array}{c}1.11 \\
(1.05)\end{array}$ & $\begin{array}{c}1.20 \\
(1.09)\end{array}$ & $\begin{array}{c}1.16 \\
(1.07)\end{array}$ \\
\hline M2. & $\begin{array}{c}\text { Trichogramma sp.@15,0000/ha + HaNPV@300 LE/ha } \\
+ \text { + NSKE @10\% }\end{array}$ & $\begin{array}{c}20.78 \\
(27.11)\end{array}$ & $\begin{array}{l}22.45 \\
(28.27)\end{array}$ & $\begin{array}{c}21.62 \\
(27.69)\end{array}$ & $\begin{array}{c}22.16 \\
(28.08)\end{array}$ & $\begin{array}{c}23.94 \\
(29.28)\end{array}$ & $\begin{array}{c}23.05 \\
(28.68)\end{array}$ & $\begin{array}{c}1.33 \\
(1.15)\end{array}$ & $\begin{array}{c}1.29 \\
(1.13)\end{array}$ & $\begin{array}{c}1.28 \\
(1.13)\end{array}$ \\
\hline M3. & $\begin{array}{c}\text { NSKE @10\% + HaNPV@300 LE/ha + Indoxacarb } 14.5 \\
\text { SC @ } 500 \mathrm{ml} / \mathrm{ha}\end{array}$ & $\begin{array}{l}14.92 \\
(22.71)\end{array}$ & $\begin{array}{l}15.77 \\
(23.38)\end{array}$ & $\begin{array}{c}15.34 \\
(23.05)\end{array}$ & $\begin{array}{c}15.96 \\
(23.54)\end{array}$ & $\begin{array}{l}16.84 \\
(24.22)\end{array}$ & $\begin{array}{c}16.40 \\
(23.88)\end{array}$ & $\begin{array}{c}0.96 \\
(0.98)\end{array}$ & $\begin{array}{c}0.98 \\
(0.99)\end{array}$ & $\begin{array}{c}0.97 \\
(0.98)\end{array}$ \\
\hline M4. & $\begin{array}{c}\text { HaNPV@300 LE/ha + Bt.k (dipel SL)@ } 1.5 \text { L/ha + } \\
\text { Acephate75\%SP @ } 2 \text { kg/ha }\end{array}$ & $\begin{array}{c}13.06 \\
(21.17)\end{array}$ & $\begin{array}{c}13.24 \\
(21.32)\end{array}$ & $\begin{array}{c}13.15 \\
(21.25)\end{array}$ & $\begin{array}{c}14.02 \\
(21.98)\end{array}$ & $\begin{array}{c}14.32 \\
(22.23)\end{array}$ & $\begin{array}{c}14.17 \\
(22.10)\end{array}$ & $\begin{array}{c}0.78 \\
(0.88)\end{array}$ & $\begin{array}{c}0.89 \\
(0.94)\end{array}$ & $\begin{array}{c}0.83 \\
(0.91)\end{array}$ \\
\hline M5. & $\begin{array}{c}\text { Bt.k(dipel SL) @ 1.5 L/ha + Spinosad } 45 \text { SC @ } \\
\text { 200ml/ha + Flubendiamide 48\% SC @ } 200 \text { ml/ha }\end{array}$ & $\begin{array}{c}9.96 \\
(18.37)\end{array}$ & $\begin{array}{c}10.65 \\
(19.03)\end{array}$ & $\begin{array}{c}10.31 \\
(18.70)\end{array}$ & $\begin{array}{c}10.88 \\
(19.24)\end{array}$ & $\begin{array}{l}11.58 \\
(19.87)\end{array}$ & $\begin{array}{c}11.23 \\
(19.55)\end{array}$ & $\begin{array}{c}0.56 \\
(0.74)\end{array}$ & $\begin{array}{c}0.62 \\
(0.79)\end{array}$ & $\begin{array}{c}0.59 \\
(0.77)\end{array}$ \\
\hline M6. & $\begin{array}{c}\text { Trap crop (1 row marigold):15 rows tomato + NSKE } \\
@ 10 \%+H a N P V @ 300 \text { LE/ha }\end{array}$ & $\begin{array}{c}17.17 \\
(24.47)\end{array}$ & $\begin{array}{c}18.27 \\
(25.30)\end{array}$ & $\begin{array}{c}17.72 \\
(24.88)\end{array}$ & $\begin{array}{c}18.24 \\
(25.26)\end{array}$ & $\begin{array}{c}19.44 \\
(26.14)\end{array}$ & $\begin{array}{c}18.84 \\
(25.70)\end{array}$ & $\begin{array}{c}1.16 \\
(1.07)\end{array}$ & $\begin{array}{c}1.24 \\
(1.11)\end{array}$ & $\begin{array}{c}1.20 \\
(1.09)\end{array}$ \\
\hline M7. & $\begin{array}{c}\text { Emamectin benzoate 5\% SG @ } 200 \text { ml/ha + } \\
\text { Chlorantraniliprole18.5 EC @ 150ml/ha + } \\
\text { Novaluron10 EC @ 1 L/ha }\end{array}$ & $\begin{array}{c}6.94 \\
(15.27)\end{array}$ & $\begin{array}{c}8.32 \\
(16.75)\end{array}$ & $\begin{array}{c}7.63 \\
(16.01)\end{array}$ & $\begin{array}{c}7.76 \\
(16.15)\end{array}$ & $\begin{array}{c}9.16 \\
(17.55)\end{array}$ & $\begin{array}{c}8.46 \\
(16.85)\end{array}$ & $\begin{array}{c}0.38 \\
(0.61)\end{array}$ & $\begin{array}{c}0.49 \\
(0.70)\end{array}$ & $\begin{array}{c}0.43 \\
(0.66)\end{array}$ \\
\hline M8. & & $\begin{array}{c}29.18 \\
(32.59)\end{array}$ & $\begin{array}{c}30.47 \\
(33.80)\end{array}$ & $\begin{array}{c}30.08 \\
(33.25)\end{array}$ & $\begin{array}{c}31.24 \\
(34.04)\end{array}$ & $\begin{array}{c}33.15 \\
(35.14)\end{array}$ & $\begin{array}{c}32.24 \\
(34.59)\end{array}$ & $\begin{array}{c}1.80 \\
(1.34)\end{array}$ & $\begin{array}{c}2.07 \\
(1.44)\end{array}$ & $\begin{array}{c}1.93 \\
(1.39)\end{array}$ \\
\hline & Y (Year) & - & - & 0.84 & - & - & 0.90 & & & 0.04 \\
\hline & $\mathrm{T}$ (Treatment) & 0.72 & 0.65 & 0.45 & 0.68 & 0.80 & 0.47 & 0.03 & 0.03 & 0.02 \\
\hline & $Y \times T$ & - & - & 0.69 & - & - & 0.74 & & & 0.03 \\
\hline & Y (Year) & - & - & 2.44 & - & - & 2.63 & & & 0.11 \\
\hline & $\mathrm{T}$ (Treatment) & 2.20 & 1.97 & 1.29 & 2.07 & 2.42 & 1.38 & 0.10 & 0.09 & 0.05 \\
\hline & $\mathrm{Y} \times \mathrm{T}$ & - & - & NS & - & - & NS & & & NS \\
\hline
\end{tabular}

* Figures in parenthesis are arcsin transformed values, while those outside parenthesis are retransformed values

** Figures in parenthesis are square root transformed $(\sqrt{ } x)$ values, while those outside parenthesis are original values 


\subsection{Fruit Damage}

The results on fruit damage caused by fruit borer on number and weight basis showed that module 7 comprising Emamectin benzoate 5\% SG @ $200 \mathrm{ml} / \mathrm{ha}+$ Chlorantraniliprole18.5 EC@ 150ml/ha + Novaluron 10 EC @ 1 L/ha had lowest fruit damage of 8.46 and 7.63 per cent on number and weight basis. It was followed by module 5 comprising Bt.k (dipel SL) @ 1.5 L/ha + Spinosad 45 SC @ 200ml/ha + Flubendiamide 48\% SC @ 200 ml/ha (11.23 and 10.31 per cent), module 4 comprising HaNPV@ 300 LE/ha + Bt.k (dipel SL) @ 1.5 L/ha + Acephate75\%SP @ 2 kg/ha (14.17 and 13.15 per cent), module 3 comprising NSKE @ 10\% + HaNPV @ 300 LE/ha + Indoxacarb 14.5 SC @ 500ml/ha (16.40 and 15.34 per cent) and module 6 comprising Trap crop (1 row marigold): 15 rows tomato + NSKE @10\%+HaNPV@ 300 LE/ha (18.84 and 17.72 per cent). In order of efficacy, module 1 comprising NSKE @10\% + HaNPV @ 300 LE/ha + Bt.k (dipel SL) @ 1.5 L/ha (21.62 and 20.36 per cent) and module 2 comprising Trichogramma sp. (@ 150,000/ha + HaNPV @ 300 LE/ha + NSKE @ 10\% (23.05 and 21.62 per cent) ranked next to the above IPM modules (Table 2).

\section{Discussion}

Helicoverpa armigera is serious concern for the tomato crop farming in Northern-western India and in the world. As reported that marigold planted as one row on either side or parallel to 10 to 15 rows of tomato resulted maximum reduction of eggs population and thereby larval population of H. armigerain tomato [13]. The IPM module consisting of trap crop (15 rows of tomato: 1 row marigold) + Trichogramma pretiosum @ 45,000/ ha + NSKE $5 \%$ + HaNPV @ 250 LE/ ha + endosulfan 35 EC @ $1250 \mathrm{ml} /$ ha found significantly superior in restricting the larval population [14]. It was indicated that emamectin benzoate @ 10.0 and $8.75 \mathrm{~g}$ a.i. ha ${ }^{-1}$ was more effective against the H. armigera followed by spinosad $2.5 \mathrm{SC}$ (12.5 $\mathrm{g}$ a.i. ha $\left.{ }^{-1}\right)$ in reducing the larval population and fruit damage [15]. Similarly, it was reported emamectin benzoate @ $0.11 \mathrm{~g}$ a.i./ ha as most effective in reducing the larval population of $H$. armigerain tomato $[16,17]$.

However, Ravi et al. $[18,19,20]$ it was showed that different sequential application of microbials (HaNPV @ 1.5x1012 POB/ha and Bt formulation (Delfin) 25 WG @1 kg/ha) and neemazol were equally effective as that of sequential application of synthetic chemical insecticides viz., endosulfan 35 EC (@350 g a.i./ha), quinolphos 25 EC (@ $250 \mathrm{~g}$ a.i./ha) and indoxacarb 14.5 SC (@ $75 \mathrm{~g}$ a.i./ha) in reducing H. armigera larval population and fruit damage.

Sreekanth et al. [21, 22] showed that the number of Helicoverpa larvae per plant were lowest in plots treated with chlorantraniliprole 20 SC (0.43/plant), flubendiamide 480 SC (0.59/plant) and spinosad 45 SC (0.85/plant) as against untreated control plot (4.17/plant) with $89.7,85.9$ and 79.6 per cent larval reduction over control, respectively. Rathod et al. [23] found Bt @ $1.0 \mathrm{~kg} / \mathrm{ha}$ to be the most effective treatment which gave highest mortality of H. armigera, and was at par with B. bassiana @ $2.0 \mathrm{~kg} / \mathrm{ha}$. In case of insecticides, rynaxypyr 0.006 per cent proved to be the most effective treatment against $H$. armigera and was found statistically at par with indoxacarb 0.008 per cent.) One of experiment indicated that flubendiamide 0.004 per cent recorded minimum larval population ( 0.43 larva/ plant) and 10.09 per cent fruit damage on weight basis followed by chlorantraniliprole 0.0055 per cent (0.58 larva/plant and $10.62 \%$ fruit damage) and spinosad 0.0068 per cent $(0.68$ larva/plant and $11.34 \%$ fruit damage) which were identical [24]. Chavan et al. [25, 26] recorded the minimum larval incidence of $H$. armigera ( 0.95 and 0.36 larva/m row length) in rynaxypyr $20 \mathrm{SC}$ at 3 and 7 days after spraying followed by flubendiamide $48 \mathrm{SC}$ (1.47 and 0.78 larvae/m row length) and emamectin benzoate 5 SG (1.55 and 0.89 larvae/m row length). The present findings are in agreement to the findings of these authors.

\section{Conclusion}


The experimental trials conducted on tomato crop showed the potential of implementing integrated pest management to set up the productivity significantly by reducing the losses due to fruit borer. These modules should be demonstrated on farmers' field for assessing the performance of improved technology, after that developed module should be disseminated among the farmers.

\section{References}

1. Yusufe, Mawardii, Mohammed, Ali, Satheesh and Neela. 2017. Effect of duration and drying temperature on characteristics of dried tomato (Lycopersicon esculentum L.) cochoro variety. Acta Universitatis Cibiniensis. Series E: Food Technol. 21(1): 4150 .

2. Splittstoesser, W.E. Vegetable Growing Handbook: Organic and Traditional Methods, 3rd ed. Vannostr and Rein bold, New York, 1990; pp. 167-171.

3. Suarez, M.H.; Rodriguez, E.M.R.; Romero, C.D. Chemical composition of tomato (Lycopersicon esculentum) from Tenerife, the Canary Islands. University of La Laguna, Avda. Food Chem. 2008, 106: 1046-1056. Elsevier Ltd. Spain.

4. Department of Agriculture, Rajasthan. Area Production (rajasthan.gov.in) (1 June, 2021)

5. Butani, D.K. Insect pests of vegetable tomato. Pesticides 1977, 11:33-36.

6. Tewari, G. C.; Krishnamoorthy, P.N. Yield loss in tomato caused by fruit borer. Indian Journal of Agricultural Sciences 1984, 54: 341-343

7. Lal, O.P.; Lal, S.K. Failure of control measures against Heliothis armigera infesting tomato in heavy pesticidal application areas in Delhi and satellite towns in Western UP and Haryana. Journal of Entomological Research 1996, 20(4):355-364

8. Pareek, B.L.; Bhargava, M.C. Estimation of avoidable losses in vegetables caused by borers under semi-arid conditions of Rajasthan. Insect Environment 2003, 9:59-60.

9. Raheja, A.K. IPM Research and Development in India. Progress and priorities. In:., Recent Advances in Indian Entomology, Lal, O.P., APC Publication Pvt. Ltd., New Delhi 1996, pp.115-126.

10. Carson R. Silent Spring. Houghton Mifflin 1962, Boston, MA.

11. Chittka, L.; Menzel, R. The evolutionary adaptation of flower colour and the insect pollinators' colour vision. Journal of Comparative Physiology A: Sensory, Neural and Behavioral Physiology 1992, 171, 171-181.

12. Douglas A.E. Strategies for enhanced crop resistance to insect pests. Annu. Rev. Plant Biol. 2018, 69: 637-660

13. Srinivasan, K.; Moorthy, P.N.K.; Raviprasad, T.N. African marigold as a trap crop for the management of the fruit borer, Helicoverpa armigera on tomato. International Journal of Pest Management 1994, 40(1): 56-63.

14. Karabhantanal, S.S.; Awaknavar, J.S. Effect of integration of bio-agents and neem seed kernel extract for the management of the tomato fruit borer, Helicoverpa armigera (Hubner). Pest Management of Economic Zoology 2005, 13(1): 35-42.

15. Khanna, S.S.; Sekaran, S. C.; Regupathy, A.; Stanly, J. Field efficacy of emamectin 5 SG against tomato fruit borer Helicoverpa armigera (Hubner). Pestology 2005, 29(4): 21-24.

16. Murugaraj, P.; Nachiappam, R.M.; Selvanarayanan. Efficacy of emamectin benzoate (Proclaim 05 SG) against tomato fruit borer, Helicoverpa armigera (Hubner). Pestology 2006, 30(1): 11-16.

17. Ameta, O.P.; Bunker, G.K. Efficacy of NNI 0001 (flubendiamide) 480 SC against diamond back moth, Plutella xylostella (Linn.) in cabbage and its effects on natural enemies under field conditions. Pestology 2007, 31: 21-24.

18. Ravi, M.; Santharam, G.; Sathiah, N. Ecofriendly management of tomato fruit borer, Helicoverpa armigera (Hubner). Journal of Biopesticides 2008, 1(2): $134-137$.

19. Deshmukh, S.G.; Sureja, B.V.; Jethva D.M.; Chatar V.P. Field efficacy of different insecticides against Helicoverpa armigera (Hubner) infesting chickpea. Legume Research 2010, 33(4): 269 - 273.

20. Kumar, P.; Kumar, S.; Rana, R.; Sachan, S. K. Comparative efficacy of novel insecticides and bio-pesticides on larval population density of gram pod borer (Helicoverpa armigera Hubner) on chickpea. Journal of Plant Development Sciences 2014, 6(2): 335-338.

21. Sreekanth, M.; Lakshmi, M.S.M.; Rao, Y.K. Bio-efficacy and economics of certain new insecticides against gram pod borer, Helicoverpa armigera (Hubner) infesting pigeon pea (Cajanus cajan L.). International Journal of Plant, Animal and Environmental Sciences 2014, 4(1): 11-15

22. Katti, P.; Surpur, S. Evaluation of novaluron 5.25\% + indoxacarb 4.5\% SC (MAIRM-01 SC) against Spodoptera litura (Fab.) and Helicoverpa armigera (Hub.) on tomato. Journal of Experimental Zoology 2015, 18(2): 891-894.

23. Rathod, N.P.; Vala, G.S.; Dudhat, A.S.; Kachhadiya, N.M. Field efficacy of bio-pesticides alone and in combination with newer insecticides against Helicoverpa armigera of pigeon pea. International Journal of Plant Protection 2014, 7(1): 128-131.

24. Ambule, A.T.; Radadia, G.G.; Shinde, C.U.; Patil, D.L. Relative efficacy of newer insecticides against Helicoverpa armigera (Hubner) in tomato under South Gujarat condition. International Journal of plant protection 2015 8(1): 152-156.

25. Chavan, A. P.; Patil, S.K.; Latake, S. B. Bio-efficacy and economics of insecticides management of Helicoverpa armigera Hubner in chickpea. Annals of Plant Protection Sciences 2015, 23(1): 27-29. 
26. Patil, K.A.; Jagginavar, S.B. Bio efficacy of newer insecticide molecules against safflower capsule borer, Helicoverpa armigera (Hubner). Journal of Farm Science 2016, 29(1): 117-118. 